Nasser in the Egyptian Imaginary 
Edinburgh Studies in Modern Arabic Literature Series Editor: Rasheed El-Enany

Writing Beirut: Mappings of the City in the Modern Arabic Novel Samira Aghacy Autobiographical Identities in Contemporary Arab Literature Valerie Anishchenkova

The Iraqi Novel: Key Writers, Key Texts

Fabio Caiani and Catherine Cobham

Sufism in the Contemporary Arabic Novel

Ziad Elmarsafy

Gender, Nation, and the Arabic Novel: Egypt 1892-2008

Hoda Elsadda

Post-War Anglophone Lebanese Fiction: Home Matters in the Diaspora Syrine Hout

Nasser in the Egyptian Imaginary

Omar Khalifah

War and Occupation in Iraqi Fiction

Ikram Masmoudi

The Arab Nahdah: The Making of the Intellectual and Humanist Movement Abdulrazzak Patel

Sonallah Ibrahim: Rebel with a Pen

Paul Starkey

www.edinburghuniversitypress.com/series/smal 


\section{Nasser in the Egyptian Imaginary}

\section{Omar Khalifah}

EDINBURGH

University Press 


\section{For my parents, Khalid Khalifah and Iman Afani, my unassailable certainty}

Edinburgh University Press is one of the leading university presses in the UK. We publish academic books and journals in our selected subject areas across the humanities and social sciences, combining cutting-edge scholarship with high editorial and production values to produce academic works of lasting importance. For more information visit our website: edinburghuniversitypress.com

(C) Omar Khalifah, 2017

Edinburgh University Press Ltd

The Tun - Holyrood Road

12 (2f) Jackson's Entry

Edinburgh EH8 8PJ

Typeset in 11/15 Adobe Garamond by

Servis Filmsetting Ltd, Stockport, Cheshire, and printed and bound in Great Britain by

CPI Group (UK) Ltd, Croydon CR0 4YY

A CIP record for this book is available from the British Library

ISBN 9781474410199 (hardback)

ISBN 9781474410205 (webready PDF)

ISBN 9781474410212 (epub)

The right of Omar Khalifah to be identified as author of this work has been asserted in accordance with the Copyright, Designs and Patents Act 1988 and the Copyright and Related Rights Regulations 2003 (SI No. 2498). 